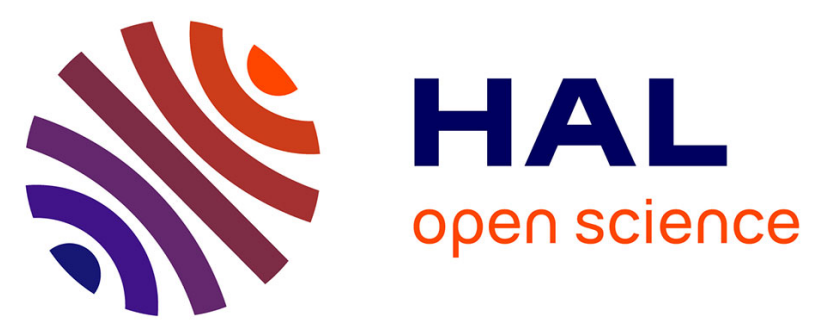

\title{
Molecular determinants of hormone sensitivity in rainbow trout glucocorticoid receptors 1 and 2
}

\author{
Armin Sturm, Louise Colliar, Michael Leaver, Nic R. Bury
}

\section{To cite this version:}

Armin Sturm, Louise Colliar, Michael Leaver, Nic R. Bury. Molecular determinants of hormone sensitivity in rainbow trout glucocorticoid receptors 1 and 2. Molecular and Cellular Endocrinology, 2011, 333 (2), pp.181. 10.1016/j.mce.2010.12.033 . hal-00668059

\section{HAL Id: hal-00668059 \\ https://hal.science/hal-00668059}

Submitted on 9 Feb 2012

HAL is a multi-disciplinary open access archive for the deposit and dissemination of scientific research documents, whether they are published or not. The documents may come from teaching and research institutions in France or abroad, or from public or private research centers.
L'archive ouverte pluridisciplinaire HAL, est destinée au dépôt et à la diffusion de documents scientifiques de niveau recherche, publiés ou non, émanant des établissements d'enseignement et de recherche français ou étrangers, des laboratoires publics ou privés. 


\section{Accepted Manuscript}

Title: Molecular determinants of hormone sensitivity in rainbow trout glucocorticoid receptors 1 and 2

Authors: Armin Sturm, Louise Colliar, Michael Leaver, Nic R. Bury

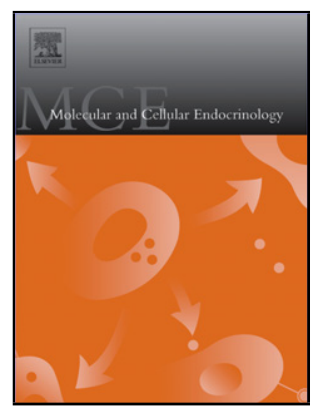

PII:

S0303-7207(11)00002-5

DOI: doi:10.1016/j.mce.2010.12.033

Reference: MCE 7738

To appear in: Molecular and Cellular Endocrinology

Received date: 26-10-2010

Revised date: 2-12-2010

Accepted date: $28-12-2010$

Please cite this article as: Sturm, A., Colliar, L., Leaver, M., Bury, N.R., Molecular determinants of hormone sensitivity in rainbow trout glucocorticoid receptors 1 and 2, Molecular and Cellular Endocrinology (2010), doi:10.1016/j.mce.2010.12.033

This is a PDF file of an unedited manuscript that has been accepted for publication. As a service to our customers we are providing this early version of the manuscript. The manuscript will undergo copyediting, typesetting, and review of the resulting proof before it is published in its final form. Please note that during the production process errors may be discovered which could affect the content, and all legal disclaimers that apply to the journal pertain. 
receptors 1 and 2

4

5 Author list: Armin Sturm ${ }^{1,2}$, Louise Colliar ${ }^{1}$, Michael Leaver ${ }^{1}$, Nic R. Bury ${ }^{2 \dagger}$

61 University of Stirling, Institute of Aquaculture, Stirling, Scotland, UK

72 King's College London, Nutritional Sciences Division, London, England, UK

8

9 † Corresponding author.

10

$11 \quad$ Tel. 00442078484091.

12 Fax. 00442078484500.

13 Email: nic.bury@kcl.ac.uk

14

15

16

17 


\section{Abstract}

20 Many teleost fish possess two glucocorticoid receptors (GR). In the rainbow trout rtGR1 and rtGR2 differ in their affinities to dexamethasone and EC50 values for glucocorticoids in transactivation assays, with rtGR2 being more sensitive. The objective of this study was to identify the molecular traits underlying the sensitivity difference. Domain-swap mutants between rtGR1 and rtGR2 showed that sensitivity was mainly determined by the hormone binding domain (E-domain). Chimeras exchanging three E-domain subregions indicated that all subregions influenced sensitivity, with the most C-terminal region that included AF2 having the greatest (12.6-fold) effects on cortisol transactivation EC50. The C-terminal extremity (CTE) in rtGR1 departs from a consensus preserved in other GRs. Introducing the consensus CTE into rtGR1 provoked a 4.2-fold decrease in transactivation EC50, suggesting CTE is one of several determinants of rtGR1's hyposensitivity. GRs with similar unusual CTEs exist in other salmonids, suggesting hyposensitive GR have evolved in this highly successful teleost lineage.

Keywords: Steroid receptors, Teleost Fish, Cortisol, Stress response, Activation Function 2, ligand binding domain 
41 Glucocorticoids are steroid hormones produced by the adrenal cortex, or the adrenal analogue of teleost fish, the interrenal cells of the head kidney (Bern, 1976). Glucocorticoids have multiple and complex functions, including roles in the regulation of glucose metabolism, growth, development, central nervous function and the immune response (Schoneveld et al., 2004 ; Charmandari et al., 2005). The majority of glucocorticoid effects occur on the transcriptional level and are mediated through the glucocorticoid receptor (GR) (Bamberger et al., 1996; Schoneveld et al 2004). In the absence of hormonal ligands, mammalian GR resides in the cytosol as part of a hetero-oligomeric complex that includes a dimer of heat shock protein (hsp) 90, one co-chaperone p23, and one tetratricopeptide repeat protein (Pratt and Toft, 1997; Heitzer et al., 2007). However, in the teleost rainbow trout unliganded GRs show a subcellular localisation that is both cytosolic and nuclear (Becker et al., 2008). Binding of glucocorticoids facilitates GR dissociation from this complex and provokes the nuclear translocation of the receptor (Schoneveld et al., 2004; Heitzer et al., 2007). In the nucleus, GR can affect transcription of target genes in various ways, including binding to regulatory DNA sequences, and engaging in protein-protein interactions with other transcription factors ( Bamberger et al., 1996; Schoneveld et al 2004). Most commonly, homodimers of GR bind to imperfectly palindromic 15-nucleotide sequences called glucocorticoid response elements, which are found in the regulatory regions of glucocorticoid target genes ( Bamberger et al., 1996).

60

Functional and structural domains have been mapped to specific regions of GR in human and rat. The $\mathrm{N}$-terminal $\mathrm{A} / \mathrm{B}$ domain of $\mathrm{GR}$ contains the receptor's main transactivation function named T1 (also called enh2 or AF1) (Giguere et al., 1986; Godowski e tal 1988).

64 The central $\mathrm{C}$ domain consists of two zinc fingers involved in GR homodimerisation and DNA binding (Hard et al., 1990), while the C-terminal E-domain functions in ligand binding and contains a second, hormone-dependent activation function called AF2 (Danieleian et al., 
1992; Kucera et al., 2002). At the C-terminal end of the E-domain, a further region with roles in transactivation has been identified and was termed T2 (Giguere et al 1986; Milhon et al., 1997). The crystal structure of the ligand-binding domain of GR has been elucidated when bound to the synthetic glucocorticoid dexamethasone and a coactivator motif (Bledsoe et al 2002), leading to the identification of amino acids involved in ligand binding.

In contrast to tetrapods, which possess one GR gene only, many teleost fish have two GRs encoded by distinct genes (Ducouret et al., 1995; Bury et al., 2003; Greenwood et al., 2003; Stolte et al., 2008a). Phylogenetic analyses have suggested a common origin of the duplication of GR in a number of teleosts (Bury et al., 2003; Stolte et al 2008a), which may have occurred in the context of a whole-genome duplication that is believed to have taken place in the actinopterygian (ray-finned fish) lineage about 300 Mya (Jaillon et al., 2004), i.e. before the emergence of teleosts (248-213 Mya) but after the divergence of sarcopterygians (lobed finned fish including tetrapods) 420 Mya. The retention of duplicated GR genes in different teleosts, including rainbow trout, Burton's mouthbrooder, pufferfish, green puffer, carp, medaka and stickleback, suggests that duplicated teleosts GRs are not redundant, but have acquired distinct functions by undergoing neo- or subfunctionalisation. Indeed, where data are available, duplicated teleost GRs have shown significant differences in hormone sensitivity and/or tissue expression (Bury et al., 2003; Greenwood et al., 2003; Becker et al 2008; Stolte et al., 2008a and b). In rainbow trout, sensitivity differences in receptor transactivation were particularly pronounced, with cortisol having an EC50 of $46 \mathrm{nM}$ in rtGR1 and of $0.72 \mathrm{nM}$ in rtGR2 in transactivation assays in the hamster cell line $\mathrm{CHO}$ (Bury et al., 2003).

The objective of this studywas to identify the molecular determinants of the sensitivity difference between rtGR1 and rtGR2. In addition, previous studies assessing teleost GR transactivational activities have all been performed in mammalian cell lines and because of the possibility that the receptor co-activator profiles differ between mammalian and fish cells 
95

96

97

98

99

100

101

102

103

104

105

106

107

108

109

110

the physiological significance of these results have been questioned. Consequently, a second objective was to assess the transactivational activities of rtGR1 and rtGR2 in a fish cell line. Understanding why the two trout GRs differ in hormone sensitivity, despite their high sequence identity in the central and C-terminal regions of the protein (Bury et al 2003), could help predict the behaviour of duplicated GRs in other teleost species. Moreover, the identification of molecular traits of GR determining hormone sensitivity could further improve the understanding of rare medical conditions based on GR mutations affecting hormone sensitivity, such as generalised glucocorticoid resistance and hypersensitivity (Charmanadari et al 2005 and 2008). In order to unravel the molecular basis of the differential sensitivity of the two trout GR receptors, we created a number of recombinant GRs, either by exchanging homologous regions between rtGR1 and rtGR2, or by introducing single or multiple amino acid mutations into the context of rtGR1 or rtGR2. The resulting mutants were tested in a transactivation assay and dexamethasone binding affinities determined. The results revealed that the E-domain of the receptors was the main determinant of sensitivity, and more specifically, the unusual C-terminal extremity of rtGR1, which departs from a consensus among other known GRs, is important for receptor hyposensitivity. 


\section{2. Materials and Methods}

112

\section{$113 \quad 2.1$ Plasmid constructs}

114 Expression constructs containing cDNAs of rtGR1 (originally called rtGR) and rtGR2 were 115 available from previous studies (Ducouret et al., 1995; Bury et al., 2003). Using appropriate

116 enzymes, rtGR1 and rtGR2 cDNAs were subcloned into pcDNA3 (Invitrogen) to yield constructs pcrtGR1 and pcrtGR2. Domain swap mutants between rtGR1 and rtGR2 were

118 produced using a two-step PCR protocol based on overlap extension (Sambrook and

119 Russell, 2001) and subcloned into pcDNA3. GRs with single and double amino acid

120 mutations were generated using mutagenic primers and a kit (QuikChange II, Stratagene).

121 Domains were defined as follows: A/B, rtGR1: amino acids 1-386, rtGR2: 1-306; C, rtGR1:

122 387-463, rtGR2: 307-379; D, rtGR1: 464-502, rtGR2: 380-419; E, rtGR1: 503-758, rtGR2:

123 420-669.

2.2 Cell culture, transactivation and binding assays.

126 COS-7 cells derived from African green monkey kidney and lacking endogenous expression

127 of functional GR were maintained and transfected using the calcium phosphate method as described previously (Becker et al., 2008), or using a modification of this method for 96-well plates (see below). During and after transfection, cells were maintained in Dulbecco's modified Eagle medium (DMEM) / nutrient mix F-12 Ham (Sigma, Poole, UK) containing 2 $\mathrm{mM}$ glutamine, $3.7 \mathrm{~g} / \mathrm{l} \mathrm{NaHCO} 3,100 \mathrm{IU} / \mathrm{ml}$ penicillin, $100 \mu \mathrm{g} / \mathrm{ml}$ streptomycin, and $2.5 \%$ denatured, dextran/charcoal-treated FCS (DMEM/F12). Per $10 \mathrm{~cm}^{2}$ of culture dish surface area, $2.5 \mu \mathrm{g}$ GR cDNA, $25 \mu \mathrm{g}$ luciferase reporter pFC31Luc (Gouilleux et al 1991) containing the murine mammary tumour virus (MMTV) promoter, $5 \mu \mathrm{g}$ control reporter pSV $\beta$ (Clontech, Palo Alto, CA), and $21 \mu \mathrm{g}$ irrelevant DNA (pBluescript SK) were used. In the modified (96well) method, COS-7 cells were seeded into 6-well plates and transfected. The next

137 morning, cells were trypsinised, resuspended in DMEM/F12, and seeded into the wells of a 
138 96-well plate while maintaining the same cell number-to-surface ratio. Cells were allowed to

139 attach for $4 \mathrm{~h}$ before starting hormone treatment.

141 FHM cells derived from fathead minnow were maintained in DMEM supplemented with 2 mM

142 glutamine, $100 \mathrm{IU} / \mathrm{ml}$ penicillin, $100 \mu \mathrm{g} / \mathrm{ml}$ streptomycin, and $10 \%$ denatured $\mathrm{FCS}$ at $22^{\circ} \mathrm{C}$ in

143 a humidified atmosphere with $4 \% \mathrm{CO}_{2}$. FHM cells were seeded into 96 -well plates $\left(6 \times 10^{5}\right.$

144 cells /well) and transfected with plasmid DNA with the help of lipofectamine 2000

145 (Invitrogen), following the manufacturer's instructions. Per well, $160 \mathrm{ng}$ of pFC31Luc, $30 \mathrm{ng}$

146 of GR expression plasmid, and $30 \mathrm{ng}$ of control reporter construct pGL4.75 (Promega) were

147 used. After transfection, cells were maintained in the above media in which the FCS was

148 replaced by charcoal/dextran treated, denatured FCS. Hormone treatment started $12 \mathrm{~h}$ after

149 transfection and continued for $36 \mathrm{~h}$, after which cells were harvested using a commercial

150 lysis reagent (Promega). Luciferase activities were determined using a modification of a

151 published method (Dyer et al 2000). To measure firefly luciferase activities (FHM and COS-

152 7), $75 \mu \mathrm{l}$ of cell lysate and $75 \mu \mathrm{l}$ of reagent one (50 mM TRIS/phosphoric acid pH 8.0, $33 \mathrm{mM}$

153 dithiothreitol, $4 \mathrm{mM} \mathrm{MgSO}_{4}, 2 \mathrm{mM}$ EDTA, $1 \mathrm{mM}$ ATP, $0.2 \mathrm{mM}$ coenzyme A, $0.38 \mathrm{mM}$ beetle

154 luciferin) were added to a black microtitre plate and luciferase activity monitored in a

155 luminometre. In assays with FHM-cells, activity of the control reporter Renilla luciferase was

156 determined by adding $75 \mu \mathrm{l}$ per well of reagent two $(0.5 \mathrm{M}$ sodium chloride, $100 \mathrm{mM}$ sodium

157 phosphate ( $\mathrm{pH}$ 5.1), $4 \mathrm{mM}$ EDTA, $0.33 \mathrm{mg} / \mathrm{ml}$ bovine serum albumin, $0.67 \mathrm{mM}$ sodium azide

158 and $1 \mu \mathrm{M}$ coelentrazine) to the same plate, which was re-read in the luminometre after 10

159 min incubation. $\beta$-Galactosidase activities (control reporter in assays with COS-7) were

160 measured as described before (Sturm et al., 2010).

162 All experiments were performed using triplicates and repeated at least three times. For each

163 receptor, a solvent control (ethanol) and an optimal glucocorticoid treatment $\left(10^{-7} \mathrm{M}\right.$

164 dexamethasone or $10^{-6} \mathrm{M}$ cortisol) were included. In further controls using empty vector

165 instead of receptor plasmid, luciferase activities were negligible regardless of hormone 
166 treatment (data not shown). Luciferase activities were divided by $\beta$-galactosidase or Renilla

167 luciferase activities to correct for differences in transfection efficiency. Luciferase activities of

168 a given receptor/hormone combination were then expressed as percent of maximum

169 activities. In the usual case, activities with the optimal glucocorticoid treatment were the

170 highest in the data set and set to $100 \%$. However, if a lower hormone concentration showed

171 a higher activity, the average of this activity and all activities at higher concentrations was set

172 to $100 \%$. To derive median effective concentrations (EC50), a logistic model was fitted to the

173 transactivation response data for each receptor, versus log concentration [S] in, assuming a

174 maximum value of $1(100 \%)$, and a minimum of zero. Assuming no differences between

175 experiments for each receptor, two parameters were to be fitted: a curve-steepness

176 parameter $b$ and the $\mathrm{EC}_{50}$ value. The model was:

$$
B_{i}=\frac{1}{1+\exp \left(-b\left(\log _{10}\left[S_{i}\right]-\log _{10} \mathrm{EC}_{50}\right)\right)}+\varepsilon_{i}
$$

179 The model was fitted for each receptor using a non-linear least-squares curve fitting

180 procedure in the R modelling environment (http://www.r-project.org/). The error term $\varepsilon$ was

181 assumed to be normally distributed for each data point $i .95 \%$ confidence intervals for $\mathrm{EC}_{50}$

182 were obtained using the $\mathrm{R}$ confint function, and are asymmetric due to the transformation of 183 concentration data.

$185\left[{ }^{3} \mathrm{H}\right]$-dexamethasone [6,7-3H(N), Perkin-Elmer) binding assays followed the protocols were 186 carried out using a whole cell assay with COS-7 cells transiently expressing the receptors 187 under investigation, as described in detail in Sturm et al., (2010). 


\section{Results}

191

192 Median effective concentrations (EC50s) of glucocorticoids in transient transfection assays monitoring the hormonal stimulation of transactivation activity on the MMTV promoter are lower for rtGR2 than for rtGR1 in two mammalian cell lines lacking endogenous functional corticosteroid receptors ( $\mathrm{CHO}$ derived from chinese hamster ovary, and COS-7 derived from monkey kidney (Bury et al., 2003)). Glucocorticoid EC50 values of the two receptors further differ in transactivation assays with other promoters and in a transrepression assay (Bury and Sturm et al 2007). However, a caveat regarding these finding is that they were obtained with mammalian cell lines that might lack co-factors required for the optimal function of teleost hormone receptors. Therefore, we investigated the hormone dependency of transactivation activity of rtGR1 and rtGR2 in transient transfection assays using the teleost cell line FHM, derived from fathead minnow. In FHM cells, cortisol EC50 values were significantly higher in rtGR1 (16.9 nM [95\% confidence limits: 12.1-23.5]) than in rtGR2 (3.6 nM [2.4-5.4]) (Fig. 1A). Similar results were obtained with dexamethasone (EC50 values: rtGR1 3.1 nM [2.2-4.2]; rtGR2 0.89 nM [0.57-1.33]) (Data not shown).

The binding of ${ }^{3} \mathrm{H}$-dexamethasone to rtGR1 and rtGR2 was studied using a whole cell assay with COS-7 transiently transfected with rtGR1 or rtGR2 (Sturm et al., 2010). Apparent affinities were expressed as the dissociation constant $K_{\mathrm{d}}$ (rtGR1: $30.4 \mathrm{nM}$, rtGR2 8.6 nM)

210 (Table 1).

212 In a transactivation assay in COS-7 cells established previously (Bury et al., 2003; Sturm et

213 al., 2005), rtGR1 and rtGR2 showed a more marked sensitivity difference with cortisol (28.8-

214 fold) (Fig. 1C) and dexamethasone (12.6-fold, Fig. 2). This difference is far greater than that observed in FHM cells (4.7-fold for cortisol and 3.5-fold for dexamethasone). Moreover,

216 much higher induction rates of transactivation activity were found in COS-7 (>100-fold) than

217 in FHM ( 15-fold) (Fig. 1B), with maximally induced transactivation activity in COS-7 being 
218 higher for rtGR1 than for rtGR2 (Fig. 1D), despite both receptors being expressed at similar

219 levels, as determined by there being no significant difference in $B_{\max }$ in the binding studies

220 (Table 1). In contrast, similar maximum activities were observed with both receptors in FHM 221 cells (Fig. 1B).

223 To identify receptor regions affecting glucocorticoid sensitivity, we generated a series of GR

224 chimeras that combined the N-terminus of either rtGR1 or rtGR2 with the C-terminus of the other receptor, with different switching points coinciding with boundaries of main receptor domains (Fig. 2A). The transactivation properties of mutants were assessed using the transient transfection assay with COS-7 cells, which because of the significantly higher induction rates offers a better signal-to-noise ratio than the assay in FHM cells (Fig. 1C, D), and further possessed the advantage of greater difference between the EC50s of the two receptors (Fig. 1C). Transactivation by all mutants was stimulated by cortisol and dexamethasone in a dose-dependent fashion, confirming that the chimeras were functional

232 (Fig. 2B and C). Recombinant receptors in which the N-terminus of rtGR2 was combined with the E-domain of rtGR1 showed cortisol EC50 values similar to that of rtGR1 (Fig. 2B), while the converse mutants, which combined the rtGR1 N-terminus with the E-domain of rtGR2, resembled rtGR2 in sensitivity (Fig. 2B). Identical trends were observed with dexamethasone (Fig. 2B). Maximum transactivation activities of mutants after treatment with optimal cortisol or dexamethasone levels varied between those observed for rtGR1 and rtGR2 with no a discernible correlation to the domain origin of mutants (data not shown). Dexamethasone binding assays revealed that mutant $A B C D(G R 1) E(G R 2)$ resembled rtGR2 in glucocorticoid affinity, while $A B C D(G R 2) E(G R 1)$ resembled rtGR1, as apparent from similar $K_{d}$ values (Table 1$)$.

243 Together, these transactivation and hormone binding results from domain-swap mutants

244 (Fig. 2, Table 1) suggested a main role of the E-domain in the glucocorticoid sensitivity of 245 receptors. Further experiments sought to identify subregions of the E-domain, affecting the 
hormone sensitivity of receptors. The E-domain is highly similar between rtGR1 and rtGR2

247 (89\% amino acid identity), and between the human GR (hGR) and either trout GR (>70\%

248 amino acid identity, Fig. 3). To elucidate which subregions of the E-domain might play a role

249 in determining receptor sensitivity to glucocorticoids, homologous E-domain regions were exchanged between receptors, paralleling a mutational strategy that has been used to unravel determinants of hormone specificity of MR and GR (Rogerson et al., 1999). For the design of mutants, three E-domain subregions were defined, the first consisting of the T2 region (Milhon et al 1997), the second of the middle portion of the $E$ domain ranging from helices 3 to the middle of helix 10, and the third comprising the AF2 region (Kucera et al., 2002) and the C-terminus of the receptor (Fig. 3). Recombinant GRs were generated, in which above E-domain region 3, or combined regions 2 and 3, were exchanged between rtGR1 and rtGR2 (Fig. 4A). All chimeras showed a dose-dependent stimulation of transactivation by glucocorticoids, with maximal activities between those of rtGR1 and rtGR2 (data not shown). Transactivation EC50s for cortisol and dexamethasone (Fig. 4B) were compared between wild type receptors, mutants exchanging parts of the E-domain, and previous mutants exchanging the entire E-domain. Results are arranged in two series of receptors. In series one, consisting of rtGR1, AB-t2-M(GR1)AF2-CT(GR2), AB-t2(GR1) M$A F 2(G R 2)$, and $A B C D(G R 1) E(G R 2)$, the $E$-domain in rtGR1 is successively replaced with that of rtGR2 (Fig. 4A), which coincided with progressive increases of sensitivity (Fig. 4B). In series two, comprised of rtGR2, AB-t2-M(GR2)AF2-CT(GR1), AB-t2(GR2) M-AF2(GR1), and $A B C D(G R 2) E(G R 1)$, the gradual substitution of the rtGR2 E-domain with that of rtGR1 lead to incremental losses of sensitivity (Fig. 4A, B).

The dimension of the effect of exchanging a particular E-domain region depended on the glucocorticoid and the receptor context. In series one, the differences in dexamethasone sensitivity between the individual receptors suggested about similar effects of all subregions (2.2- to 3.0-fold shifts of EC50) (Fig. 4B). By contrast, in the same series exchange of the

273 most C-terminal E-domain region 3 had a far greater effect on cortisol sensitivity (12.6-fold 
shift of EC50) than that of region 1 (2.7-fold) or region 2 (1.5-fold, not significant) (Fig. 4B). In series two, exchange of the middle region had the greatest effect with both hormones, causing sensitivity shifts of 8.1 - to 8.6 -fold (Fig. 4A, B). Swapping the most C-terminal region had medium effects (shifts of 1.8- to 4.6-fold), while effects of replacing the 2 region were marginal ( 1.2-fold, significant only for cortisol) (Fig. 4A, B). Despite these complexities, the results taken together suggested that region 2 and region 3 were more important for sensitivity than region 1. Dexamethasone binding properties were analysed for AB-t2M(GR1)AF2-CT(GR2) and AB-t2-M(GR2)AF2-CT(GR1) (Table 1). Paralleling the findings on dexamethasone EC50s of transactivation activity, $K_{d}$ values for these receptors were intermediary between rtGR1 and rtGR2 (Table 1).

The effects of region 2 differed between the two series of mutants shown in Fig. 4. Therefore, the effects of this part of the E-domain, which shows 11 amino acid differences between rtGR1 and rtGR2 (Fig. 3), were analysed in two further sets of mutants. The first set of recombinant GRs was derived from rtGR1 by introducing rtGR2-specific residues as single amino acid mutations or double mutations of adjacent amino acids (Table 2). In the final mutant of the first set, called GR1(M_GR2), the entire region 2 of rtGR1 was replaced by that of rtGR2. A second set of recombinant receptors consisted of the converse mutants in a rtGR2-background (Table 2). Maximum activities of the rtGR1-derived mutants were similar to those of rtGR1, while maximum activities of rtGR2-derived mutants resembled those in rtGR2 (data not shown). Whereas the introduction of the rtGR2 sequence had paradoxical desensitising effects in GR1_Y635H and GR1_T667S, EC50 values of all other rtGR-derived mutations were not significantly different from that of rtGR1 (Table 2). Among the rtGR2-derived mutants, GR2_I451L/R461Q, GR2_D509N/N511G and GR2(M_GR1) were slightly less sensitive than rtGR2 (1.6- to 2.5- fold) (Table 2).

300 Within E-domain region 3, the AF2 domain differs in two adjacent amino acids between

$301 \mathrm{rtGR} 1\left(\mathrm{Gln}{ }^{709} \| \mathrm{e}^{710}\right)$ and rtGR2 $\left(\mathrm{Asp}^{626} \mathrm{Phe}^{627}\right)$ (Fig. 3). The second of these residues 
302 corresponds to hGR $\operatorname{Tyr}^{735}$ (Fig. 3), which is involved in ligand binding ( Ray et al., 1999;

303 Bledsoe et al., 2002). To explore potential effects of this two-amino acid-difference on

304 receptor sensitivity, the mutants GR1_Q709D/I710F and GR2_D626Q/F627I were made.

305 According to EC50 values obtained in our transactivation assay, GR1_Q709D/I710F was

306 more sensitive than rtGR1 to cortisol, but less sensitive to dexamethasone (Fig. 5B).

307 Similarly, GR2_D626Q/F627I was less sensitive to cortisol than rtGR2, but more sensitive to

308 dexamethasone (Fig. 5B). Maximal transactivation activities of rtGR1 and

309 GR1_Q709D/I710F were in a similar range, as were those of rtGR2 and GR2_D626Q/F627I

310 (data not shown). Apparent dexamethasone binding affinities, expressed as $K_{\mathrm{d}}$, of receptors

311 GR1_Q709D/I710F and GR2_D626Q/F627I only showed slight, statistically insignificant

312 changes compared to the affinities of the corresponding wild-type receptor (Table 1).

314 A second striking difference between rtGR1 and rtGR2 in region 3 regards the C-terminus,

315 where the sequence of rtGR1 is highly unusual. Here, rtGR2 conforms to a consensus

316 amongst other known GRs, which have Gln-Lys or Gln-Arg as the terminal amino acids

317 (Milhon et al 1997; Kucera et al 2002). By contrast, rtGR1 shows the amino acids Ala-Leu at

318 the corresponding positions, and further possesses six additional C-terminal amino acids

319 lacking in other GRs (Fig 3). Mutants were derived from rtGR1 introducing changes to the C-

320 terminus (Fig. 5A). In GR1_A751Q/L752K, change of residues 751 and 752 to the

321 consensus had moderately sensitising effects on transactivation EC50s with cortisol (2.1-

322 fold) and dexamethasone (2.5-fold) (Fig. 5B). The further ablation of the additional C-

323 terminal residues in GR1-CTcons resulted in additional sensitivity shifts of transactivation

324 EC50s of about 1.5-fold (Fig. 5B), making GR1-CTcons 3.1- and 4.2-fold more sensitive than rtGR1 to cortisol and dexamethasone, respectively (Fig. 5B). GR1_A751Q/L752K and GR1CTcons were similar to rtGR1 regarding maximal transactivation activities (data not shown).

327 Combining rtGR1 mutations Q709D, I710F, A751Q and L752K resulted in a receptor being

328 4.9-fold more sensitive to cortisol in transactivation assays than rtGR1, but only 1.4-fold

329 more sensitive to dexamethasone (Fig. 5B). Mutants GR1_A751Q/L752K and GR1-CTcons 
330 displayed 2.6-fold and 2.0-fold lower dexamethasone $K_{\mathrm{d}}$ values, respectively, than the wild

331 receptor rtGR1 (Table 1).

\section{Discussion}

Despite their high sequence similarity in the central and C-terminal regions, rtGR1 and rtGR2 markedly differ in their EC50 values for glucocorticoids in transactivation and transrepression assays in mammalian cell lines (Ducouret et al 1995; Bury et al 2003). The present study confirmed this finding for the first time in a teleost cell line (Fig. 1A), excluding the possibility that the difference in transactivation assays sensitivity reported earlier had been caused by the heterologous expression. In the current study the two GRs also showed a significantly different (3.5-fold) apparent dissociation constant for dexamethasone; a result that contrasts to our original observation of a smaller difference (1.6-fold) in dexamethasone affinity between the receptors (Bury et al., 2003). The reasons for the discrepancy are unknown, but the current study uses a whole cell assay for assessment of dexamethasone binding characteristics, whereas our previous study used a cell free expression system. However, distinct dexamethasone binding affinities would help explain the downstream differences in transactivation and transrepression assays EC50 values seen in previous studies (Bury et al., 2003; Bury and Sturm, 2007). In accordance with this hypothesis, domain-swap mutants between rtGR1 and rtGR2 show that the main determinant of glucocorticoid transactivation EC50 sensitivity resides in the hormone binding (E) domain of the receptors, and there is a clear correlation $\left(R^{2}=0.86\right)$ between the transactivation EC50

352 value and the $K_{\mathrm{d}}$ value of dexamethasone among all wildtype and mutant GRs tested (Fig.

353 6). However, experiments in which three subregions of the E-domain were defined and exchanged between rtGR1 and rtGR2 demonstrated that all subregions contributed to the overall sensitivity shift. Effects of the most $\mathrm{N}$-terminal E-domain subregion were strongly dependent on the receptor context, while those of the central and C-terminal subregions showed effects in all exchange mutants. At the C-terminal extremity, rtGR1 deviates from a 
consensus sequence present in all other known GRs except for a few GRs in species closely related to rainbow trout (Fig. 7). Here we show for the first time a role of this unique sequence as a determinant of the relatively cortisol hyposensitivity of rtGR1.

362 To map determinants of receptor hormone sensitivity to specific regions of the E-domains, we generated recombinant GRs that exchanged homologous parts of the E-domain between rtGR1 and rtGR2 (Fig. 4). The effects of exchanging region 1 were highly dependent on receptor context, suggesting that they involve other parts of the receptor, and do not directly reflect differences in the strength of the т2-region between rtGR1 and rtGR2. In line with this interpretation, amino acids involved in hormone binding and transactivation in the mouse GR (Milhon et al., 1997) are either conserved in both trout GRs, or show conservative substitutions (Fig. 3). The т2-region has been identified as the main determinant of glucocorticoid hyposensitivity in the guinea pig GR, and it has been noted that this receptor is more similar to rtGR1 than to hGR in this region (Keightley et al., 1998). However, the T2domain of the later isolated rtGR2 also is highly similar to that of the guinea pig GR, suggesting that the similarity of the $\mathrm{T2}$-domains of rtGR1 and the guinea pig GR is not directly related to the low hormone sensitivity of the receptors.

Exchanging E-domain region 2 also had variable effects, depending mainly on the receptor context. There was a marked difference in glucocorticoid EC50 values of transactivation between recombinant receptors containing the rtGR1 region 2 compared to those with rtGR2 region 2 for those chimeras in which the $\mathrm{N}$-terminal part of the receptor was from rtGR2 and the C-terminal part was from rtGR1. In contrast, there was little if any effect of the origin of region 2 on glucocorticoid EC50 values in the converse mutants having an $\mathrm{N}$-terminus originating from rtGR1 and a C-terminus derived from rtGR2. The effects of region 2 of the-E domain were further explored in mutants, in which single or multiple amino acids of region 2 of the respective other receptor were introduced into a rtGR1 or rtGR2 background. In this region, rtGR1 and rtGR2 differ in 11 amino acids, none of which is involved in ligand binding 
386 (Bledsoe et al., 2002). Interestingly, exchanging the entire region 2 of rtGR1 for that of rtGR2

387 had no effect on dexamethasone EC50s in transactivation assays, while the converse

388 mutant in which region 2 of rtGR2 was substituted for that of rtGR1 showed a significantly

389 increased EC50 (Table 2). This suggests that region 2 is necessary but not sufficient in

390 conferring to a receptor the capability to respond to dexamethasone at lower concentrations.

392 Among chimeras differing in parts of the E-domain, exchanging the third, most C-terminal,

393 region had the most consistent effects in that differences in glucocorticoid EC50s in

394 transactivation assays and $K_{d}$ values in binding studies. In this region, one sequence

395 difference between the two trout receptors (rtGR1 Ile ${ }^{710}$, rtGR2 Phe ${ }^{627}$ ) corresponds to a 396 residue involved in ligand binding in hGR (Tyr ${ }^{735}$, Fig. 2, (Ray et al., 1999; Bledsoe et al., 397 2002). Indeed, mutations that converted this and the preceding amino acid in one of the 398 trout GRs to the sequence found in the other trout GR, GR1_Q709D/I710F and

399 GR2_D626Q/F627I, provoked moderate sensitivity shifts of transactivation EC50s in the 400 expected direction with cortisol ( 2.0-fold, Fig. 5). Surprisingly, however, and difficult to 401 explain, EC50s of dexamethasone were shifted in the opposite direction.

402

403 Another striking difference in region 3 between rtGR1 and rtGR2 regards the C-terminal extremity of receptors. While in all other known GRs, Gln-Lys or Gln-Arg are conserved at the two most C-terminal amino acids, rtGR1 shows the amino acids Ala-Leu at the corresponding positions, and further has six additional amino acids C-terminal to this site.

407 Introducing the consensus C-terminus into rtGR1 had a consistent, if moderate, effect on 408 glucocorticoid EC50 values in transactivation assays (3.1- to 4.2-fold) and on apparent 409 dexamethasone binding affinities (2.0- to 2.6-fold). In the crystal structure of hGR, a C-

410 terminal $\beta$-strand following the AF2 helix formed a conserved $\beta$-sheet with a $\beta$-strand

411 between helices 8 and 9, suggesting its importance in receptor activation by stabilising the 412 "active" conformation of the AF2-helix (Bledsoe et al., 2002). The divergent C-terminus of 413 rtGR1 is located directly C-terminally of the C-terminal $\beta$-strand (Fig. 3). Our observation that 
414 the non-consensus C-terminus of rtGR1 contributes to its hyposensitivity suggests the

415 possibility that it might affect the stability of the "active" conformation of the AF2-helix.

416 Previous studies have identified mutations located in the C-terminal part of GR that

417 negatively affect hormone sensitivity, such as mouse GR Y770N (corresponding to pos. 764

418 of hGR) from a glucocorticoid resistant cell line (Zhang et al., 1996), and hGR L773P from a

419 patient showing signs of generalised glucocorticoid resistance (Charmanadari et al., 2005).

420

421 To identify other GRs deviating from the C-terminal sequence consensus, tblastn searches

422 were carried out on the website of the National Centre for Biotechnology Information, using

423 E-domain region 3 of rtGR1 (Fig. 3) as the query. This yielded two GR sequences departing

424 from the C-terminal consensus, one in brown trout (Salmo trutta) and one in Atlantic salmon

425 (Salmo salar), two salmonid species closely related to rainbow trout (Fig. 7A). The brown

426 trout GR C-terminus is identical to that of rtGR1. The Atlantic salmon sequence resembles

427 rtGR1, but shows an insertion of one His after the conserved Leu-Leu-Phe and a far longer

428 C-terminal extension than rtGR1 (33 amino acids compared to 6 in rtGR1) (Fig. 7A). In

429 addition to the above salmonid GR sequences, the tblastn search hit a number of teleost

430 nucleotide GR sequences, in which reading the translation frame past the stop codon

431 yielded a predicted amino acid sequence with striking similarities to the C-terminal extension

432 found in rtGR1 (Fig. 7B). This suggests that the peculiar rtGR1 sequence might have

433 evolved by a mutation of the consensus stop codon.

435 A previous study provided an evolutionary analysis of available teleost GR sequences

436 including those from genome assemblies for zebrafish, puffer, green puffer, Japanese

437 medaka and three-spined stickleback (Stolte et al., 2006). Teleost GRs formed two well

438 supported clades, suggesting that duplications of GR in teleosts trace back to one ancient

439 gene duplication. The retention of duplicated GR genes in many species suggests these are

440 not redundant, but have undergone neo- or subfunctionalisation. In contrast, the zebrafish

441 genome contains one GR gene only (Schaaf et al., 2008 and 2009), which could indicate a 
442 secondary loss of one of the GR gene copies. Duplicated GRs have been cloned and

443 functionally characterised in rainbow trout and two further teleost species, Burton's

444 mouthbrooder and common carp (Bury et al., 2003; Greenwood et al., 2003). In contrast to

445 trout, the maximal variability in cortisol sensitivity among GR isoforms was relatively

446 moderate in Burton's mouthbrooder (2.6-fold) and carp (7.3-fold) (Greenwood et al., 2005;

447 Stolte et al., 2008). This shows that the pronounced sensitivity difference found between

448 rtGR1 and rtGR2 is a specific trait of GRs in this teleost. The identification of a C-terminal

449 sequence significantly contributing to the hyposensitivity of rtGR1, which departs from a

450 consensus among GRs except for similar sequences in two other salmonids, suggest that

451 following the duplication of GRs in an ancestor of teleosts, one of the two GRs might have

452 mutated into a hyposensitive GR in the salmonid lineage.

453

454 Whether a hyposensitive receptor offers specific selective advantages is unclear, and awaits

455 further physiological studies to elucidate the physiological roles of the two receptors in

456 salmonids and other teleosts.

457

458

459 


\section{Acknowledgements}

461

462 This work was supported by Grant S18960 from the UK Biotechnology and Biological

463 Sciences Research Council (to N.R.B.) and by Grant NE/F008287/1 from the UK Nature and

464 Environment Research Council (to L.C.). We thank different colleagues for kindly placing

465 plasmids at our disposal. Dr. B. Ducouret supplied pCMrtGR, Dr. P. Prunet gave pCMrtGR2,

466 and pFC31Luc was a gift from Dr. F. Gouilleux. We are grateful to Professor M.-E. Rafestin-

467 Oblin and Dr. J. Fagart for their fruitful comments on the manuscript. We thank Dr. D. M.

468 Green for advice on biometrical analyses in the modelling environment R.

469

470 


\section{References}

472 Bamberger C.M., Schulte, H.M., Chrousos, G.P. 1996. Molecular determinants of 473 glucocorticoid receptor function and tissue sensitivity to glucocorticoids. Endocr. Rev. $474 \quad 17: 245-61$

475

476 Barton, B.A., Iwama, G.K. 1991. Physiological changes in fish from stress in aquaculture

477 with emphasis on the response and effects of corticosteroids. Annual Review of Fish

478 Diseases 1:3-26

479

480 Becker, H., Sturm, A., Bron, J.E., Schirmer, K., Bury, N.R. 2008. The A/B domain of the 481 teleost glucocorticoid receptors influences partial nuclear localization in the absence of 482 hormone. Endocrinology 149:4567-4576

483

484

Bern, H.A. 1967. Hormones and endocrine glands of fishes. Science 158:455-462

485

Charmandari, E., Tsigos, C., Chrousos, G. 2005, Endocrinology of the stress response. Annu. Rev. Physiol. 67:259-284

487

Bledsoe, R.K., Montana, V.G., Stanley, T.B., Delves, C.J., Apolito, C.J., McKee, D.D., Consler, T.G., Parks, D.J., Stewart, E.L., Willson, T.M., Lambert, M.H., Moore, J.T., Pearce, K.H., Xu, H.E. 2002. Crystal structure of the glucocorticoid receptor ligand binding domain reveals a novel mode of receptor dimerization and coactivator recognition. Cell 110:93-105

493 Bury, N.R., Sturm, A., Le Rouzic, P., Lethimonier, C., Ducouret, B., Guigen, Y., Robinson494 Rechavi, M., Laudet, V., Prunet, P. 2003. Evidence for two distinct functional glucocorticoid receptors in teleost fish. J. Mol. Endocrinol. 31:141-156

497 Bury, N.R., Sturm, A. 2007. Evolution of the corticosteroid receptor signalling pathway in 498 fish. Gen. Comp. Endocrinol. 153:47-56 
500 Charmandari, E., Raji, A., Kino, T., Ichijo, T., Tiulpakov, A., Zachman, K., Chrousos, G.P.

501 2005. A novel point mutation in the ligand-binding domain (LBD) of the human glucocorticoid

502 receptor (hGR) causing generalized glucocorticoid resistance: The importance of the C

503 terminus of hGR LBD in conferring transactivational activity. Journal of Clinical

504 Endocrinology and Metabolism 90:3696-3705

505

506 Charmandari, E., Ichijo, T., Jubiz, W., Baid, S., Zachman, K., Chrousos, G., Kino, T. 2008 A

507 novel point mutation in the amino terminal domain of the human glucocorticoid receptor

508 (hGR) gene enhancing hGR-mediated gene expression. Journal of Clinical Endocrinology \&

509 Metabolism 93:4963-4968

510

511 Danielian, P.S., White, R., Lees, J.A., Parker, M.G. 1992. Identification of a Conserved

512 Region Required for Hormone Dependent Transcriptional Activation by Steroid-Hormone

513 Receptors. EMBO J. 11:1025-1033

514

515 Ducouret, B., Tujague, M., Ashraf, J., Mouchel, N., Servel, N., Valotaire, Y., Thompson, E.B. 1995. Cloning of a teleost fish glucocorticoid receptor shows that it contains a

517 deoxyribonucleic acid-binding domain different from that of mammals. Endocrinology

$518 \quad 136: 3774-3783$

519

520 Dyer, B.W., Ferrer, F.A., Klinedinst, D.K., Rodriguez, R. 2000. A noncommercial dual

521 luciferase enzyme assay system for reporter gene analysis. Anal. Biochem. 282:158-161 522

523 Giguere, V., Hollenberg, S.M., Rosenfeld, M.G., Evans, R.M. 1986. Functional Domains of

524 the Human Glucocorticoid Receptor. Cell 46:645-652 
526 Godowski, P.J., Picard, D., Yamamoto, K.R. 1988. Signal Transduction and Transcriptional

527 Regulation by Glucocorticoid Receptor-Lexa Fusion Proteins. Science 241:812-816

529 Gouilleux, F., Sola, B., Couette, B., Richard-Foy, H. 1991. Cooperation between structural

530 elements in hormono-regulated transcription from the mouse mammary tumor virus

531 promoter. Nucleic Acids Res. 19:1563-9

532

533 Greenwood, A.K., Butler, P.C., White, R.B., DeMarco, U., Pearce, D., Fernald, R.D. 2003.

534 Multiple corticosteroid receptors in a teleost fish: distinct sequences, expression patterns,

535 and transcriptional activities. Endocrinology 144:4226-36

536

537

Hard, T., Kellenbach, E., Boelens, R., Maler, B.A., Dahlman, K., Freedman, L.P.,

538 Carlstedtduke, J., Yamamoto, K.R., Gustafsson, J.A., Kaptein, R. 1990. Solution Structure of

539 the Glucocorticoid Receptor DNA-Binding Domain. Science 249:157-160

540

541 Heitzer, M.D., Wolf, I.M., Sanchez, E.R., Witchel, S.F., DeFranco, D.B. 2007. Glucocorticoid

542 receptor physiology. Reviews in Endocrine \& Metabolic Disorders 8:321-330

544 Jaillon, O., Aury, J.M., Brunet, F., Petit, J.L., Stange-Thomann, N., Mauceli, E., Bouneau, L.,

545 Fischer, C., Ozouf-Costaz, C., Bernot, A., Nicaud, S., Jaffe, D., Fisher, S., Lutfalla, G.,

546 Dossat, C., Segurens, B., Dasilva, C., Salanoubat, M., Levy, M., Boudet, N., Castellano, S.,

547 Anthouard, V., Jubin, C., Castelli, V., Katinka, M., Vacherie, B., Biemont, C., Skalli, Z.,

548 Cattolico, L., Poulain, J., De Berardinis, V., Cruaud, C., Duprat, S., Brottier, P., Coutanceau,

549 J.P., Gouzy, J., Parra, G., Lardier, G., Chapple, C., McKernan, K.J., McEwan, P., Bosak, S.,

550 Kellis, M., Volff, J.N., Guigo, R., Zody, M.C., Mesirov, J., Lindblad-Toh, K., Birren, B.,

551 Nusbaum, C., Kahn, D., Robinson-Rechavi, M., Laudet, V., Schachter, V., Quetier, F.,

552 Saurin, W., Scarpelli, C., Wincker, P., Lander, E.S., Weissenbach, J., Roest Crollius, H. 
553

554

555

556

557

558

559

560

561

562

563

564

565

566

567

568

569

570

571

572

573

574

575

576

577

578

579

580

2004. Genome duplication in the teleost fish Tetraodon nigroviridis reveals the early

vertebrate proto-karyotype. Nature $431: 946-57$

Keightley, M.C., Curtis, A.J., Chu, S., Fuller, P.J. 1998. Structural determinants of cortisol resistance in the guinea pig glucocorticoid receptor. Endocrinology 139:2479-85

Kucera, T., Waltner-Law, M., Scott, D.K., Prasad, R., Granner, D.K. 2002. A point mutation of the AF2 transactivation domain of the glucocorticoid receptor disrupts its interaction with steroid receptor coactivator 1. J. Biol. Chem. 277:26098-26102

Milhon, J., Lee, S., Kohli, K., Chen, D., Hong, H., Stallcup, M.R. 1997. Identification of amino acids in the tau 2-region of the mouse glucocorticoid receptor that contribute to hormone binding and transcriptional activation. Mol. Endocrinol. 11:1795-805

Pratt, W.B., Toft, D.O. 1997. Steroid receptor interactions with heat shock protein and immunophilin chaperones. Endocr. Rev. 18:306-360

Prunet, P., Sturm, A., Milla, S. 2006. Multiple corticosteroid receptors in fish: from old ideas to new concepts. Gen. Comp. Endocrinol. 147:17-23

Ray, D.W., Suen, C-S, Brass, A., Soden, J., White, A. 1999. Structure/function of the human glucocorticoid receptor: Tyrosine 735 is important for transactivation. Mol. Endocrinol. 13:1855-1863

Rogerson, F.M., Dimopoulos, N., Sluka, P., Chu, S., Curtis, A.J., Fuller, P.J. 1999. Structural determinants of aldosterone binding selectivity in the mineralocorticoid receptor. J. Biol. Chem. 274:36305-11 
581 Sambrook, J., Russell, D.W. 2001. Molecular cloning, Third ed. Cold Spring Harbor

582 Laboratory Press, Cold Spring Harbor, NY, USA

583

584 Schaaf, M.J.M., Champagne, D., van Laanen, I.H.C., van Wijk, D., Meijer, A.H., Meijer, O.C., 585 Spaink, H.P., Richardson, M.K. 2008. Discovery of a functional glucocorticoid receptor betaisoform in zebrafish. Endocrinology 149:1591-1599

587

588 Schaaf, M.J.M., Chatzopoulou, A., Spaink, H.P. 2009. The zebrafish as a model system for 589 glucocorticoid receptor research. Comparative Biochemistry and Physiology a-Molecular \& $590 \quad$ Integrative Physiology 153:75-82

591

592 Schoneveld, O., Gaemers, I.C., Lamers, W.H. 2004. Mechanisms of glucocorticoid

593 signalling. Biochimica Et Biophysica Acta-Gene Structure and Expression 1680:114-128

595 Stolte, E.H., Verburg van Kemenade, B.M.L., Savelkoul, H.F.J., Flik, G. 2006. Evolution of 596 glucocorticoid receptors with different sensitivity. J. Endocrinol 190. 17-28.

598 Stolte, E.H., de Mazon, A.F., Leon-Koosterziel, K.M., Jesiak, M., Bury, N.R., Sturm, A., 599 Savelkoul, H.F.J., van Kemenade, B., Flik, G. 2008a. Corticosteroid receptors involved in 600 stress regulation in common carp, Cyprinus carpio. J. Endocrinol. 198:403-417

601

602 Stolte, E.H., Nabuurs, S.B., Bury, N.R., Sturm, A., Flik, G., Savelkoul, H.F.J., Kemenade, B. 2008b. Stress and innate immunity in carp: Corticosteroid receptors and pro-inflammatory cytokines. Molecular Immunology 46:70-79

605

606 Sturm, A., Bury, N., Dengreville, L., Fagart, J., Flouriot, G., Rafestin-Oblin, M.E., Prunet, P.

607 2005. 11-deoxycorticosterone is a potent agonist of the rainbow trout (Oncorhynchus

608 mykiss) mineralocorticoid receptor. Endocrinology 146:47-55 
609

610 Sturm, A., Bron, J.E., Green, D.M., Bury, N.R. 2010. Mapping of AF1 transactivation

611 domains in duplicated rainbow trout glucocorticoid receptors. J Mol Endocrinol 45, 1- 14

612

613 Zhang, S.M., Liang, X.Y., Danielsen, M. 1996. Role of the C terminus of the glucocorticoid

614 receptor in hormone binding and agonist antagonist discrimination. Mol. Endocrinol. 10:24-

$615 \quad 34$

616

617

618

619 
622 Figure 1. Functional properties of rtGR1 and rtGR2. Transactivation profiles (A and $C)$ and maximum induced transcriptional activities at $10^{-6} \mathrm{M}$ cortisol or dexamethasone (B and $\mathrm{D}$ ) in transiently transfected with GR, a firefly luciferase reporter containing the MMTV promoter, and in FHM cells Renilla luciferase internal reporter or in COS-7 cells $\beta$ - galactosidase internal reporter to correct for transfection efficiency. Cells were treated for $36 \mathrm{~h}$ with cortisol. After determination of reporter gene activities, transactivation activities were obtained by normalising luciferase activity to activity of the internal reporter and expressed as percent of maximal activities. AU: arbitrary units. Values represent mean \pm SE of at least 3 separate experiments.

632

Figure 2. Transactivation properties of domain-swap chimeras between rtGR1 and rtGR2.

634 Transactivation assays were carried out in COS-7 cells as described in the legend of Figure 1. (A). Graphical representation of the domain composition of recombinant domain-swap mutants. Percentages indicate amino acid identities between rtGR1 and rtGR2 for the main receptor domains. (B). Median effective concentrations (EC50s) and 95\% confidence limits of the stimulation of transactivation activity by cortisol and dexamethasone. Numbers at bars denote the EC50 in nM. EC50s are considered significantly different if confidence limits do not overlap. Values represent mean \pm SE of at least 3 separate experiments.

642 Figure 3. Alignment of the E-domains of rtGR1, rtGR2 and human GR alpha, prepared with

643 ClustalW. Conserved residues are marked with “*”, while ":" denotes conservative amino 644 acid changes. The т2 region (Nilhon et la., 1997) and the AF2 region (Kucera et al., 2002) 645 are marked by grey shadowing. The crystal structure of hGR (Bledsoe et al., 2002) has

646 identified amino acids involved in ligand binding (bold underlined), receptor homo-

647 dimerisation (embossed/underlined) and coactivator binding (italics/underlined). The position 
648 of helices $(\mathrm{H})$ and beta-strands $(\mathrm{B})$ of hGR are according to the Protein Knowledgebase

649 (UniProtKB, http://www.uniprot.org/, Accession number P04150). For the generation of

650 mutants described in Figure 4, the following subregions of the E-domain were defined:

651 Region 1 coincides with the $\mathrm{T} 2$ domain, region 3 is comprised of the AF2 domain and the C-

652 terminal extremity of the receptor, and region 2 is the middle portion of the E-domain 653 enclosed by regions 1 and 3.

654

655 Figure 4. Transactivation properties of chimeras exchanging parts of the E-domain between 656 rtGR1 and rtGR2. Transactivation assays were carried out in COS-7 cells as described in

657 the legend of Figure 1. (A). Graphical representation of the domain composition of chimeras 658 where M represents the middle portion of E-domain. (B). Median effective concentrations 659 (EC50s) and 95\% confidence limits of the stimulation of transactivation activity of receptors 660 and mutant receptors by cortisol and dexamethasone. Numbers at bars denote the EC50 in 661 nM. EC50s are considered significantly different if confidence limits do not overlap. Values 662 represent mean \pm SE of at least 3 separate experiments.

663

664 Figure 5. Transactivation properties of rtGR1- and rtGR2-derived mutants with changes in 665 the AF2 domain or C-terminal extremity. Transactivation assays were carried out in COS-7 cells as described in the legend of Figure 1. (A). Sequence information for C-terminal of wildtype rtGR1 and rtGR2 and mutants generated. (B), Median effective concentrations (EC50s) and 95\% confidence limits of the stimulation of transactivation activity of receptors and mutant receptors by cortisol and dexamethasone. GR1_709/710, GR2_626/627,

670 GR1_709/710/751/752 refers to specific site directed mutations; see 3. Results for more

671 details. Numbers at bars denote the EC50 in nM. EC50s are considered significantly 672 different if confidence limits do not overlap. Values represent mean \pm SE of at least 3 673 separate experiments. 
675 Figure 6 . The relationship between the dexamethasone binding affinity $\left(\mathrm{K}_{\mathrm{d}}\right)$ and the

676 dexamethasone EC50 of transactivation activity for wild-type and recombinant GRs studied.

677

678 Figure 7. Homology of the C-terminal extremity of rtGR peptide to other sequences. (A).

679 Alignment of hGRa and GRs from salmonid fish. Dots represent residues or gaps identical to

680 hGR $\alpha$ (top). btGR, brown trout (Salmo trutta) GR (GenBank accession number AY863149) ;

681 asGR, Atlantic salmon GR (Salmo salar) (EG879323). (B). The homology of rtGR1 to the

682 conceptual translation of different teleost mRNA GR sequences extends to the region past

683 the stop codon (\#). bm, Burton's mouthbrooder (AF263738), zf zebrafish (EF436284), fm

684 fathead minnow (AY533141). Conserved residues are marked with "*”, while ":" denotes

685 conservative amino acid changes. 
Table 1. Dexamethasone binding to wild type and mutant trout GRs, as determined in a whole cell assay with COS-7 cells transiently expressing the receptors.

\begin{tabular}{|c|c|c|c|}
\hline Receptor & $\mathbf{n}$ & $K_{\mathrm{d}}(\mathrm{nM})$ & $B_{\max }($ nmoles/well $)$ \\
\hline$r \mathrm{rtGR} 1^{\mathrm{a}}$ & 4 & $30.4(23.0-37.8)^{b}$ & $1.21 \pm 0.80^{c}$ \\
\hline $\mathrm{rtGR}^{\mathrm{a}}$ & 4 & $8.6(6.6-10.6)$ & $1.85 \pm 0.79$ \\
\hline $\mathrm{ABCD}(\mathrm{GR} 1) \mathrm{E}(\mathrm{GR} 2)$ & 3 & $9.5(8.2-10.8)$ & $2.33 \pm 0.90$ \\
\hline ABCD(GR2)E(GR1) & 3 & $35.9(26.7-45.1)$ & $1.33 \pm 0.75$ \\
\hline AB-t2-M(GR1)AF2(GR2) & 3 & $18.4(13.0-23.7)$ & $2.40 \pm 0.46$ \\
\hline AB-t2-M(GR2)AF2(GR1) & 3 & $13.7(12.1-15.2)$ & $3.59 \pm 1.72$ \\
\hline GR1_709/710 & 3 & $36.1(27.2-45.1)$ & $1.57 \pm 1.08$ \\
\hline GR2_626/627 & 2 & $8.1(6.7-9.2)$ & $2.81 \pm 2.09$ \\
\hline GR1-CTcons & 3 & $14.9(12.9-17.0)$ & $1.62 \pm 1.49$ \\
\hline GR1 $751 / 752$ & 3 & $11.6(9.1-14.0)$ & $1.47 \pm 0.94$ \\
\hline
\end{tabular}


Table 2. Median effective concentrations (EC50) of dexamethasone-dependent stimulation of transactivation activity of wild-type and mutant GRs.

\begin{tabular}{ll}
\hline Receptor & EC50 (nM) \\
\hline rtGR1 & $4.4(3.8-5.3)^{*}$ \\
rtGR2 & $0.60(0.48-0.76)$ \\
GR1_L534I/Q544R & $3.9(3.1-4.8)$ \\
GR1_S555A & $5.9(4.6-7.7)$ \\
GR1_N592D/G594N & $4.6(3.5-6.3)$ \\
GR1_D606Q/E607D & $4.0(3.1-5.2)$ \\
GR1_T615A & $4.8(3.8-5.9)$ \\
GR1_T626S & $5.0(4.3-5.8)$ \\
GR1_Y635H & $18.2(15.4-21.5)$ \\
GR1_T667S & $6.1(5.4-7.0)$ \\
GR1_(M_GR2) & $3.7(2.8-4.7)$ \\
& \\
GR2_I451L/R461Q & $0.98(0.80-1.20)$ \\
GR2_A472S & $0.62(0.48-0.81)$ \\
GR2_D509N/N511G & $1.0(0.85-1.2)$ \\
GR2_Q523D/D524E & $0.34(0.20-0.56)$ \\
GR2_A532T & $0.34(0.21-0.54)$ \\
GR2_S543T & $0.51(0.34-0.78)$ \\
GR2_H552Y & $0.55(0.23-1.2)$ \\
GR2_S584T & $0.57(0.45-0.72)$ \\
GR2 (M_GR1) & $1.5(1.3-1.6)$ \\
\hline
\end{tabular}

* Values were derived from data of at least three independent experiments, and numbers in brackets are $95 \%$ confidence limits of the EC50. 
Fig. 1
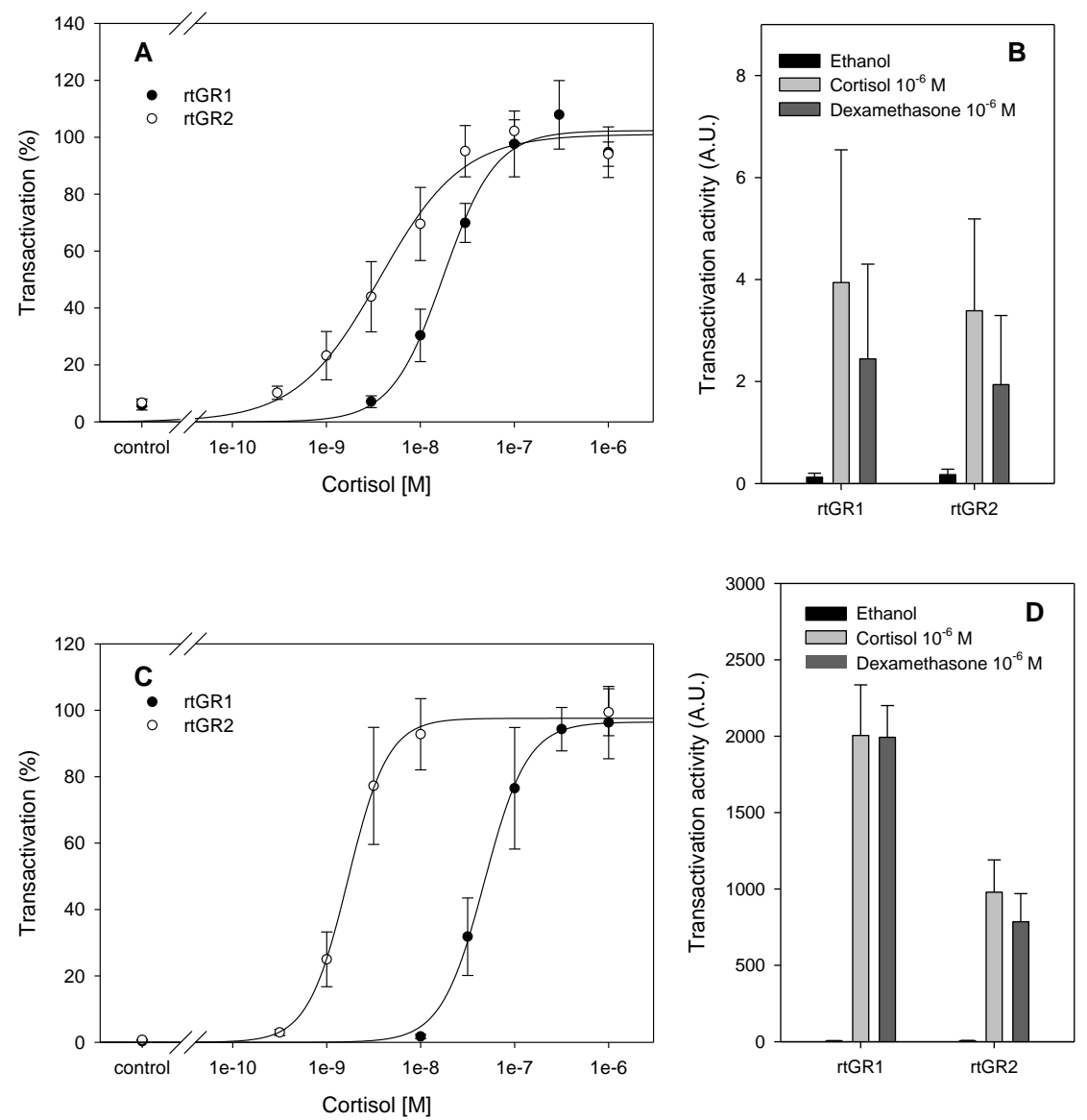
Fig 2

A

B

C
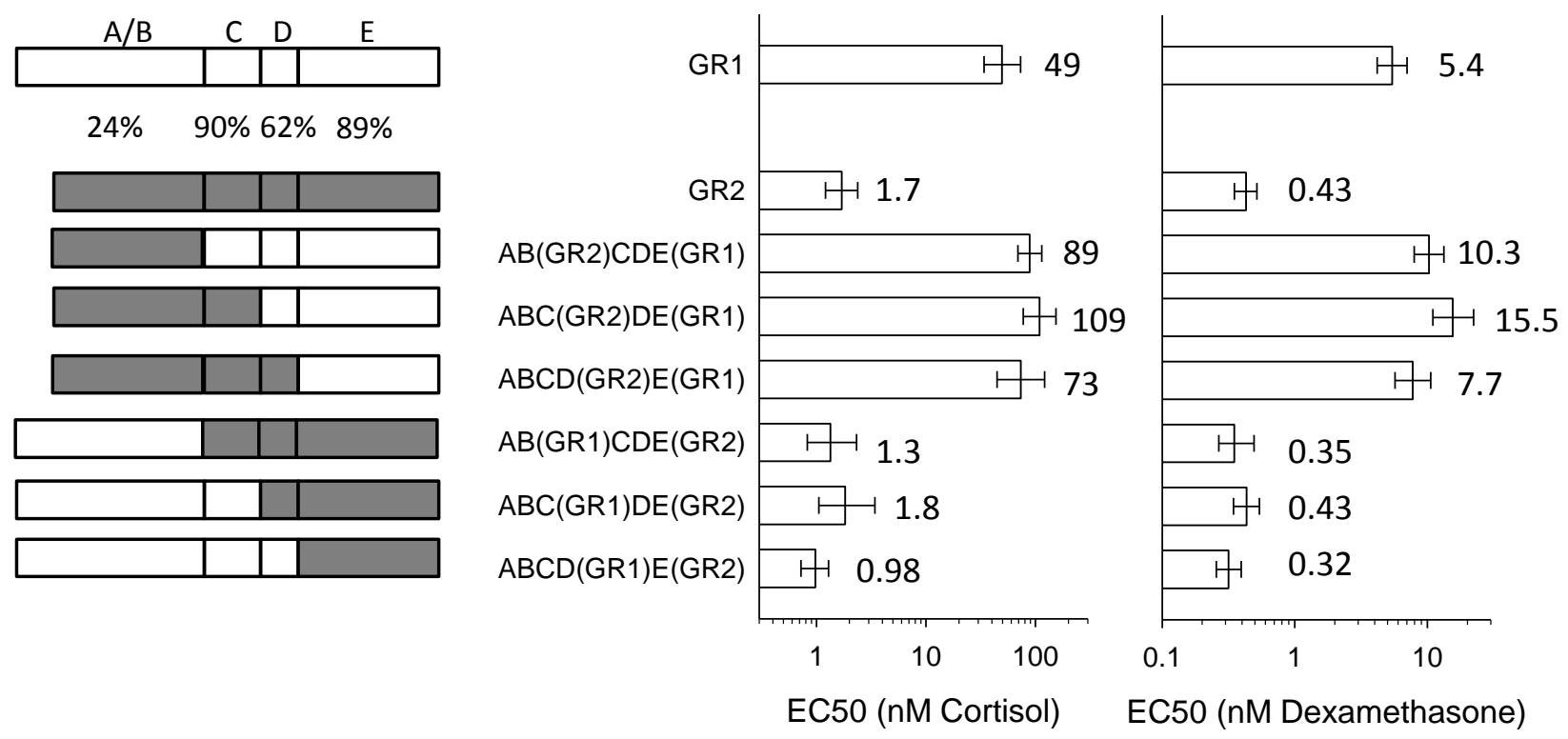
Fig. 3

hGRa

GR1

GR2

hGRa

GR1

GR2

hGRa

GR1

GR2

GRa

GR1

GR2

hGRa

GR1

GR2

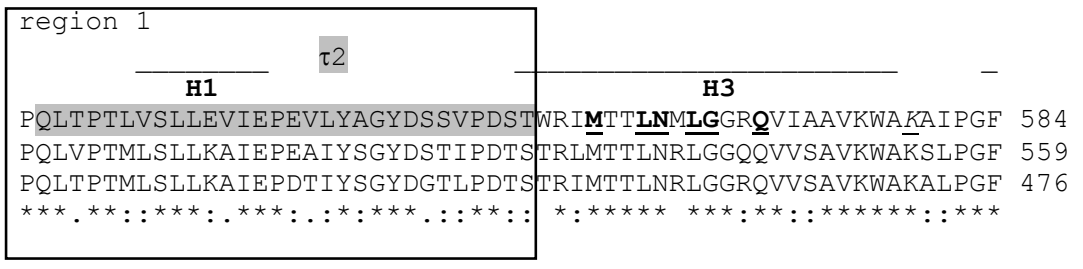

H4

\section{H5}

B

B

46

H7

RNLHLDDQMTLLQYSWMFLMAFALGWRSYRQSSANLLCFAPDL I INEQRMTLPCMYDQCK 644 RNLHLDDQMTLLQCSWLFLMSFGLGWRSYQQCNGGMLCFAPDLVINDERMKLPYMTDQCE 619 RNLHLDDQMTLLQCSWLFLMSFGLGWRSYQQCDGNMLCFAPDLVINQDRMKLPYMADQCE 536

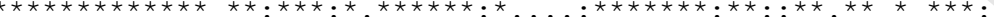

$$
\text { H7 }
$$

$$
\text { B }
$$

HMLYVSSELHRLQVSYEEYLCMKTLLLLSSVPKDGLKSQELFDEIRMTYIKELGKAIVKR 704 QM̄LKISTEFVRLQVSYDEYLCMKVLLLLSTVPKDGLKSQAVFDEIRMTYIKELGKAIVKR 679 OMLKISSEFVRLOVSHDEYLCMKVLLLLSTVAKDGLKSOAVFDEIRMSYIKELGKAIVKR 596

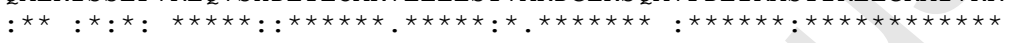

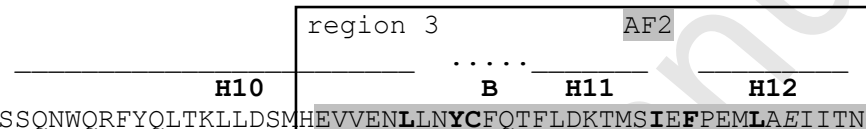

EGNSSQNWQRFYQLTKLLDSM HEVVENLLNYCFQTFLDKTMSIEEPEMLAEI ITNQI PKY

EENSSQNWQRFYQLTKLLDSMQEMVGGLLQICFYTFVNKSLSVEFPEMLAEI I SNQLPKF

EENSSONWORFYQLTKLLDSM HEMVGGLLDFCFYTFVNKS LSVEFPEMLAEI ISNOLPKF

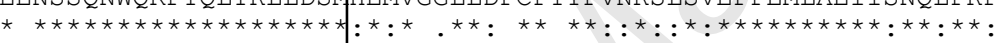

region 3

$\ddot{B}$

SNGNIKKLLFHQK------ 777

KDGSVKPLLFHALNHDTMP 758

KAGSVKPLLFHQK------ 669

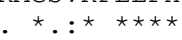


Fig 4

A

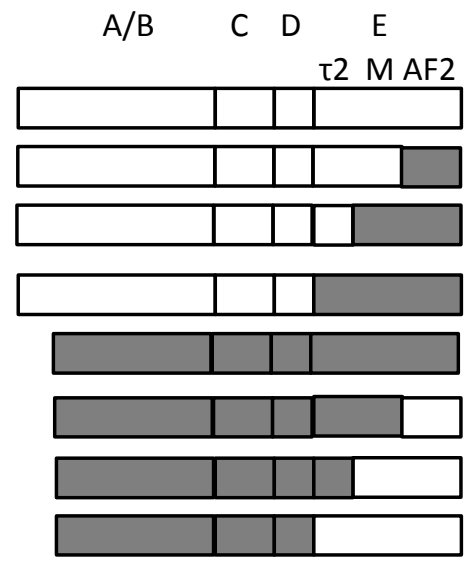

B

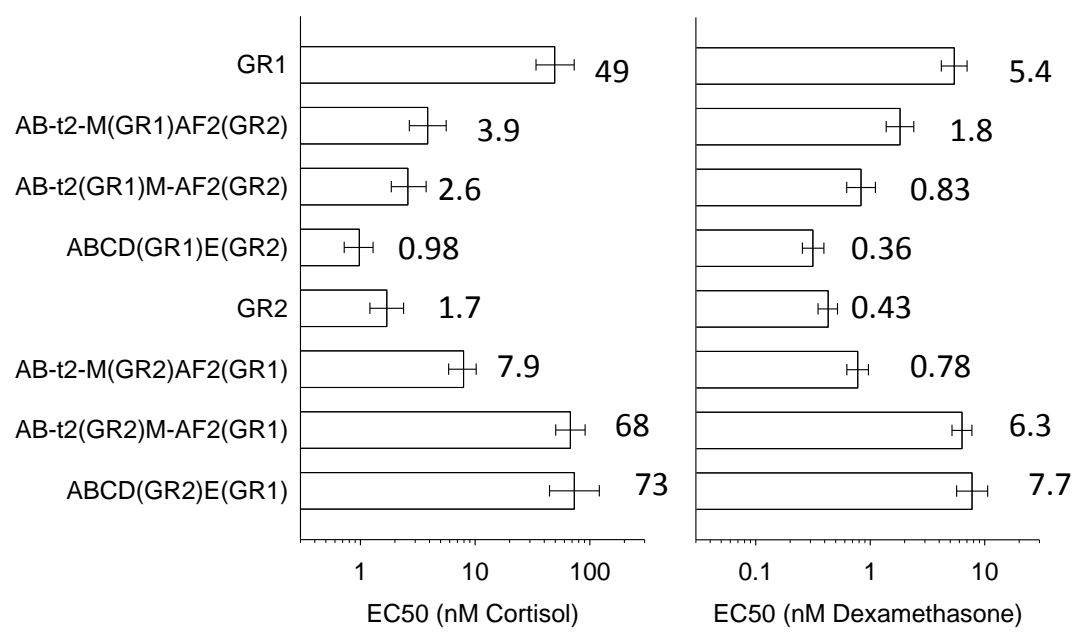


Fig. 5

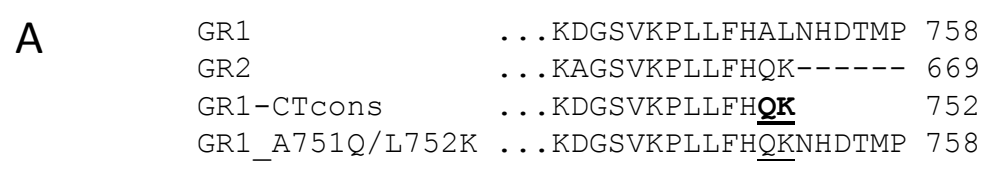

B
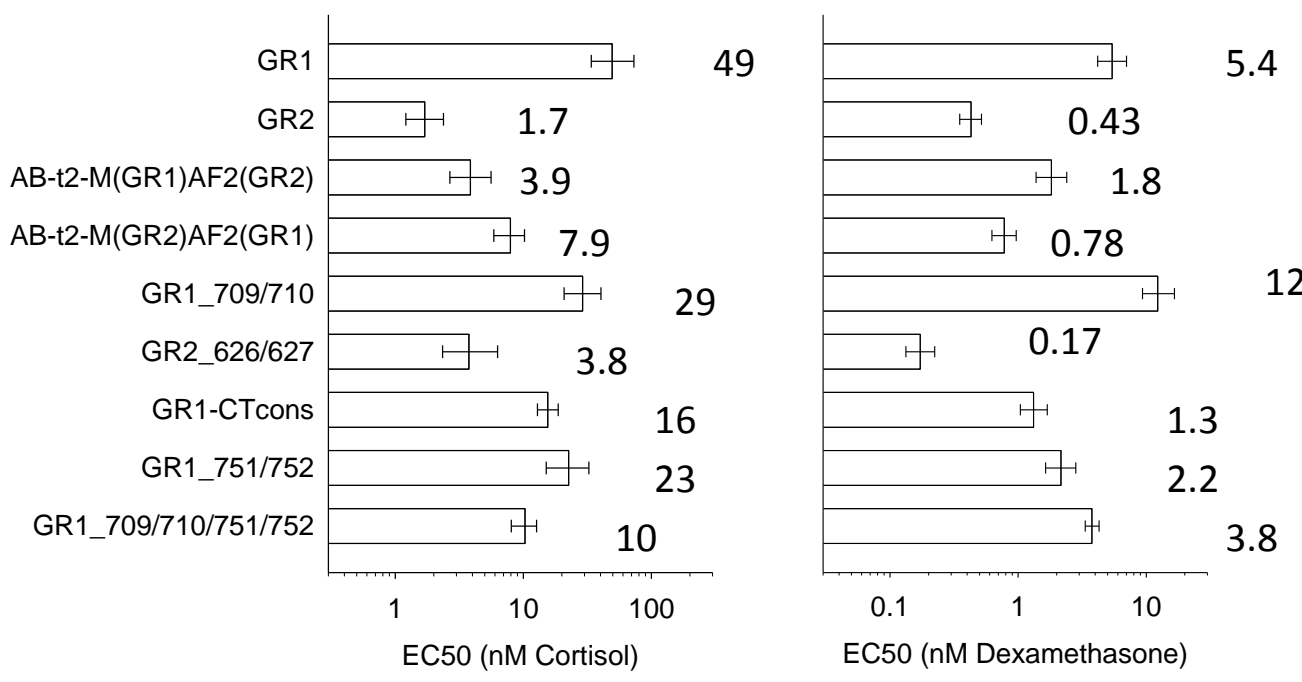
Figure 6

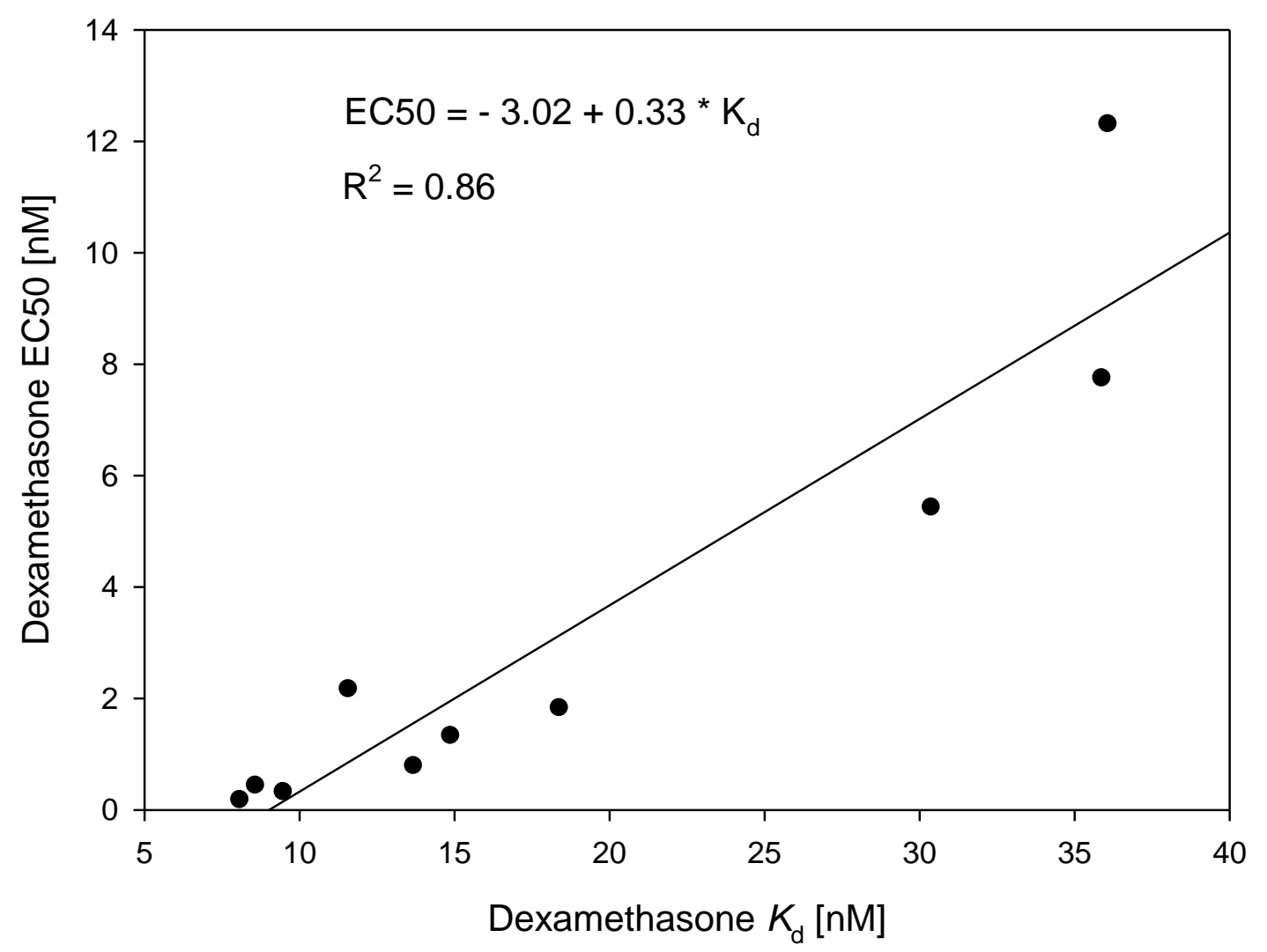


Fig. 7

A

hGRa

rtGR1

rtGR2

btGR

asGR

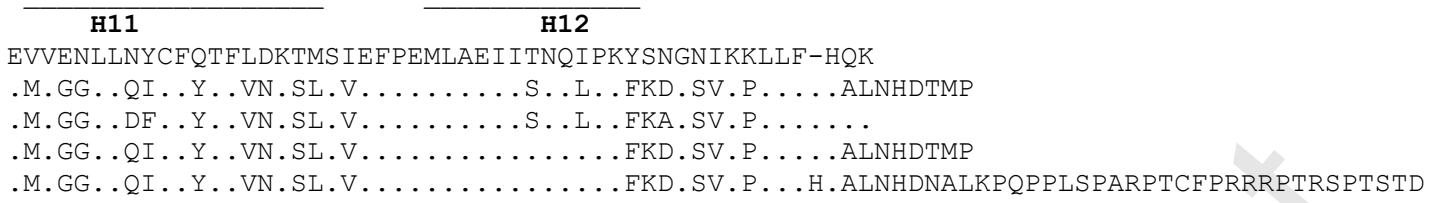

B

rtGR 1

bmGR1

$z f G R$

EMVGGLLQICFYTFVNKSLSVEFPEMLAEIISNQLPKFKDGSVKPLLFH--ALN---HDTMP EMVGGLLSFCFYTFVNKSLSVEFPKMLAEI I SNQLPKFKAGSVKPLLFHQR\# LTPV-TDTMP DLVGGLLNFCFYTFVNKSLSVEFPEMLAEI ISNQLPKFKDGSVKPLLFHQK\# I S SQQQDTMP DMVGGLLNFCFFTFVNKSLSVEFPEMLAEI ISNQLPRFRAGSVKALLFHHK\# ISSQQQDTMP

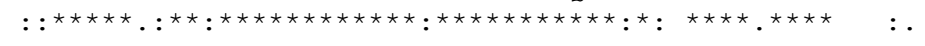

